Вісник ЛНУ імені Тараса Шевченка № 2 (325), 2019

УДК 81'243:81'25

doi: 10.12958/2227-2844-2019-2(325)-153-162

\author{
Demchenko N.A. \\ kafedrargflnu@gmail.com \\ https://orcid.org/0000-0001-5158-2328 \\ $\mathrm{PhD}$, Associate Professor, \\ Department of Theory and Practice of Translation, \\ Luhansk Taras Shevchenko National University \\ Poltava, Ukraine
}

\title{
CHOICE AND ORGANIZATION OF EDUCATIONAL MATERIAL FOR INTERPRETERS TRAINING CONSECUTIVE TRANSLATION
}

The analysis of the scientific and methodological literature has shown that the issue of teaching translation as a whole and interpretation in particular has traditionally been of considerable interest. A scientifically based holistic translation theory has been developed. Among the specialists who created the school of translation should be called L.S. Barkhudarova, V.N. Komissarova, L.K. Latyshev, Ya.I. Retsker, I. Korunets, V. Karaban and many others. Among foreign experts it can be named S. Campbell, J.C., Catford, J. Munday, E. Nida H.C. Barik, A.I. Bartolomé, G. Cabrera, R. Chriss, Y. Gambier, D.A. Garretson, I. Garcia, who have made an undoubted contribution to the development of translation studies . Formation of professional skills of future translators is considered, as a rule, in the context of certain aspects: the features of type of interpretation and the problems of various components formation of the translation competence.

The primary aim of this paper is to discuss modern concept of teaching oral consecutive translation and the formation of professional translation competence in the training of specialists in higher education. The author will rely primarily on reviewing the already existing body of literature. The article presents theoretically justified the requirements for the selection of educational materials and blocks of exercises in teaching oral sequential translation of linguistic students. This information can be helpful for organization of work with the students whose specialty is translation.

The changed world put forward new requirements for foreign language proficiency as it is becoming more open and globalized. The last decade has created a need for many people to master a foreign language, regardless of what they do. New social and political conditions put forward the necessity to train specialists who are able to promote mutual understanding between nations and to provide access to the diversity of world politics and culture. A social order for interpreters training has become of primary importance. In this respect there is a need for training specialists with foreign language skills. The need for qualified translators becomes quite urgent, and the training of such 
specialists requires both high theoretical and considerable practical knowledge and skills to accomplish the tasks. A special role among foreign language skills plays the translation skills. The quality of higher education is characterized by a significant professional orientation of the educational process, a profile-oriented selection of educational material, which, in turn, should be focused on both the achieved and the promising level of knowledge and skills. The issue of training the students to translate in general and interpretation in particular has traditionally been of considerable interest.

Formation of professional skills of future translators is considered in the context of certain aspects: the features of interpretation and the problems of various components formation of the translation competence are revealed. Translation activity is divided into oral and written one, depending on the form of generation and perception of the translated text.

The materials must be original. Dealing with authentic, cognitively valuable learning materials can provide trainees with an opportunity to discover the national culture. The selection of the original material corresponds to the linguistic purpose of learning, and is also able to increase the motivation of students. Textual material should be supplied with explanations, comments and commentaries so that students can use them during the training. However, at the final stage of preparation, students should be presented with unfamiliar and unprepared materials, which should be translated from the first time.

The selection of original materials should be carried out in accordance with the level of difficulties and the text size [Retsker 2010]. That is, the material must be available at a certain level of study for the student could assimilate material consciously.

The teaching material should take into consideration the specific features of oral speech; thereby make the training translation closer to the real conditions of a professional translator work. Oral speech is full of clichés, stereotypical expressions, speech formulas, winged words, idioms and etc. When selecting materials for teaching interpreting, it is necessary to highlight typical translation difficulties.

In the modern era, the activity of a translator provides intercultural communication. The teaching material should contribute to the student horizon broadening. The development of skills "will give possibilities to compare the phenomena of native and foreign cultures. It will improve the ways of achieving mutual understanding of two communicants, and therefore contain national specific lexical units of the linguistic community and the main characteristics of the native culture of learners. "A rich lingual-cultural text is of a motivational significance for students"; when working with such texts, students activate the following groups of motives: social, intellectual and cognitive, professional and holistic, emotional and aesthetic, moral and ethical, communication, etc.

The scope of the material should not be only relevant, linguistic and culturally rich, but also as broad as possible, using a variety of genres of 
interpreting texts (speeches, discussions, negotiations, interviews, public speech, reports, etc.), and styles (publicist, conversational) because the work of the interpreter is not limited with one genre. The topics of educational texts should reflect the requirements and interests of the modern market in the field of translation services. An analysis of the existing requirements for hiring an interpreter has shown that employers prefer specialists who are able to carry out bilingual communication, as well as taking into account the sociocultural characteristics of communicators, the situation of communication, and literacy of oral speech. Applicants are also required to ensure the precise lexical and semantic content of the original as well as the stylistic one. At the same time, enterprises emphasize the importance of the employee's readiness to provide interpretation of various sub-types, such as the translation of presentations, public events, commercial negotiations, and escort of delegations.

Great attention should be paid to the selection of audio and video materials that poses a particular difficulty. I.S. Alekseeva notes that the translator needs the skill of perceiving the individual characteristics of pronunciation, voice, temperament [Alekseeva 2008: 130-132]. Indeed, participating in video interviews or presentations or recorded voices "do not take into account the interests of potential interpreters, do not speak specially to the interpreter (that is, specially taking into account the interests of the interpret in order to increase the adequacy of communication") Chuzhakin 2009: 66]. In this regard, it is reasonable to use materials at different tempos: slow, fast, with acceleration or deceleration. It is also very rational to offer students audio-video recordings for homework, either for the purpose of decoding them, or for reviewing audio material.

Interpreter training should ensure the acquisition of knowledge and skills. It is precisely the right exercises that contribute to the optimal learning process. Actually, the purpose of the exercises is the development of skills and abilities to overcome difficulties, the nature of which is largely determined by a specific combination of languages. It is necessary to select the exercises in such a way that they correspond to the peculiarities of certain skills or abilities and focus the attention of students on solving a particular translation tasks. The sequence of exercises should be correctly determined for carrying out their relationship at all stages of training.

There are some types of exercises: pre-translational exercises and the actual translation ones. Pre-translational exercises are aimed to improve the knowledge of the target language (compilation of synonymic series and differentiation of the meanings of synonyms, stylistic evaluation of the proposed options, rephrasing of statements, etc.).The goal of the actual translation exercises is to develop the skills for overcoming the difficulties associated with the peculiarities of semantics and certain language units, as well as to "work out" the skills to use various methods and techniques of translation. The exercises are a significant part of the translation training course. In the process of working with exercises, ways of overcoming 
translation difficulties are studied; translation techniques and skills are developed.

To define a typology of effective exercises is an important component of the optimal students' learning activities in mastering the specialty of an interpreter; therefore we try to pay special attention to the selection and preparation of exercises, the fulfillment of which is due to the characteristics and specifics of the organization of interpretation.

As a rule, exercises in all types of speech activity form a certain system, within which interrelated actions are performed. The usage of certain language unites is realized in the order of their increasing difficulties and take into account the sequence of formation of certain skills and abilities. There are numerous classifications of exercise types and subtypes. But in relation to teaching consecutive translation the following types of exercises are distinguished:

1. In accordance with the type of speech activity:

- receptive exercises that contribute to the mastery of the ability to perceive language material in the process of listening and reading;

- productive exercises associated with the generation of statements (orally or in writing);

- receptive-productive exercises designed to develop the ability to analytically perceive the outgoing text and construct a statement allowing the structural and semantic aspects of speech;

- language exercises involve the selection of individual language phenomena (features of the semantics and use of certain types of language units) and their special training;

- operational exercises aim to develop the ability to apply the studied models, transformations and translation techniques in the translation process; communication exercises aimed to improve the skills and develop the speech skills and involve various manipulations in the reproduction of audiovisual text, namely, tasks of different levels, which consist of transmitting the content of the original: short / full presentation, translationretelling, control of text understanding, etc.;

- training exercises directed to the formation of translation skills and consolidation of acquired knowledge.

2. According to the method of implementation:

- audible / visual exercises designed for perception with an acoustic / visual analyzer;

- monolingual / bilingual exercises in which they do not use / use their native language;

- exercises performed in the source language / target language;

- classroom / extracurricular exercises involving work at practical classes on interpretation / independent work outside the classroom hours schedule using Internet technologies; 
- individual / group exercises, characterized by a high level of autonomy and relying on the individual characteristics of students (mental, psychological, physiological) / vigorous activities of all students.

It is worth mentioning that any type of exercise can be either monolingual or bilingual, can be performed in the source language or in the target language, can be performed in the classroom or at home using Internet technologies, and can also involve both individual and group work depending on the goals of a particular task.

The choice of exercises depends on the need for more systematic and regular work on those difficult phenomena, language features, the specifics of the actions performed, which forms the interpreter work. It should be emphasized that each type of exercise involves one or another type of training: memory training (language, communication exercises); training of two-way translation and switching from language to language (receptive-productive, language exercises); training of tempo and technique of oral (translated) speech (receptive-productive, communicative exercises).

Speaking about the subtypes of exercises aimed at the development of translation skills and abilities, it should be mentioned that the most exercises used in different schools of translation are: memory training exercises, exercises training switching from language to language, tempo training, oral / translation techniques and etc.

It is reasonable to analyze the subtypes of exercises and their importance in the formation of the translation competence of future specialists. They are:

1. Paragraphed translation. Bilateral consecutive translation. As we said above, paragraph-phrase and two-sided translations are not independent types of translation, they are subspecies, varieties of sequential translation. A paragraph-phrase translation is a simplified form of a consecutive translation without making notes, in which the text is translated after listening, not by making notes, but in parts, as a rule, by phrases and paragraphs. The translation can be one-way, which is carried out only from one language, and bilateral - a consecutive translation, carried out from one foreign language to another foreign language and vice versa.

2. The future translator will have to make one-way and two-way translation. For practicing one-way translation, we offer consistent translation after listening or using the written notes of some phrases and small paragraphs of the text, which helps to improve such skills as a good understanding of oral speech, simultaneous listening / reading, and memorization, as well as developing correct speech. Two-way translation is the translation of dialogical speech (conversations, negotiations, etc.). As a rule, these are small statements that sound in two languages. This operation requires the translator to respond quickly, analyze and synthesize, and to demonstrate the skill of switching from one language to another. The exercises for developing this skill are proposed and aimed at the automatic use of the consolidated equivalent pairs. Listening to the speaker the students translate the first sentence from a foreign language 
into Ukrainian and the second from Ukrainian into a foreign language, and so on. Then, on the contrary, they translate the first sound phrase into English from Ukrainian and the second one from English, and so on. In this case the tempo of utterance may vary.

3. Translation from a written variant. Translation from a written variant is a type of interpretation that is close to a written translation, since the information is perceived not by listening comprehension but by visual perception. At the same time "perception, analysis and synthesis occur simultaneously, as in the case of interpretation" [Chuzhakin 2009: 62]. Translation from a written variant with minimal preparation or on the spot is a task that the translator-referent, secretary-referent, and also any interpreter often have to face. It should be noted that the translation from a written variant may be difficult for an inexperienced translator. As a result the interpreter's mistakes can be in the form of literal words, a misrepresentation of meaning and etc. Proverbs, stable phrases, false friends of the translator, grammatical structures can also cause difficulties during translation. So, at the initial stage of teaching the students translation from a written variant they are trained to translate without long pauses, avoiding literal words and loan translation. They are taught not to be at a loss when they meet an unfamiliar word or phrase but try to guess the meaning based on the context. The students do not have to force the memory, because the text is fixed before their eyes. Subsequently, translation from a written variant is performed at a fast tempo, which contributes to the development of the ability to cover quickly the entire text, paying attention to the syntactic structure of the phrase, the semantics of words, and the scope of their use. Thus, a translation from a written variant effectively develops a number of skills and abilities. Further consolidation of lexical and syntactic equivalents is achieved with the help of this type of exercises. They develop the ability of quick usage of translational transformations and teach the students to follow the style of the text. A quick translation from a written variant containing a variety of lexical, phraseological and syntactic difficulties "contributes to an increase of the skill flexibilities" [Shiryaev 1979: 150]. The analyzed system of exercises will encourage and develop the ability of a student to be able to present both the presentation of the translation and reading the next piece of the text the simultaneously.

4. Translation (written) of sound records. The main goal of written translation of sound recordings is the development of listening skills. The scholars (R.K. Minyar-Beloruchev, N.N. Gavrilenko, V.N. Komissarov, I.I. Khaleeva, and others) determined the following factors of the specific features of listening skills in terms of consecutive interpretation :1) the perception of voice messages; 2) detailed understanding and processing of the semantic content of the source information; 3) the creation of their own statements, namely the translation. N.N. Gavrilenko (1990) considers listening as an important intermediate stage of the translator's activity and notes that the professional ability of translating listening consists of a complete and accurate 
understanding of the original message. The development of listening skills implies the ability to predict the continuation of the message, keeping in mind its content. This type of activity requires special skills and can be used in independent (extracurricular) work of students in accordance with their own tempo of learning. This type of tasks allows individualizing the process of learning speed perception type of students.

5. Lexical exercises. Interpretation implies knowledge of the most frequent, commonly used translation correspondences and automated skills of their use. But the problem is that many lexical units of two languages do not fully coincide with their meanings. It is about compatibility, or rather, about the violation of the traditional compatibility of words. It is not enough to know meanings of words. It is necessary to know their compatibility in a particular language. Phrase translation mistakes can cause serious stylistic violations, as well as lead to a violation of the norms of a language. Word by word translation is a common mistake. Translator teaching requires exercises on compatibility and their various permissible versions in Ukrainian and English. Compatibility patterns requires special attention and separate memorization. Offered as independent work assignments for the compilation of equivalent pairs and their subsequent repetition and consolidation at a fast tempo in the class contribute to the creation of persistent associations the development of speech stereotypes. Working with these exercises reduces the possibility of violation of the norms of lexical compatibility when translating from one language to another. Assignments for the compilation of synonymous series are also proposes. N.V. Novoseltseva (2004) emphasizes the importance of identifying and studying synonymy in the process of learning interpreting, since it develops a sense of language among the trainees and contributes to the development of translation techniques. It is important to know as many synonyms as possible for each semantic field, in order to prevent tautology. The task of these exercises is in the process of accumulating semantic knowledge, in forming the ability to accurately select from lexical diversity and use synonyms in the translation activity to convey a language message.

6. Translational transformations. The notion of translation quality is often associated with the ability of the translator to apply translational transformations that require translation solutions. In this regard the famous scientist, translator and teacher A.V. Fedorov emphasizes the importance of linking translation theory with practice, since "theory opens up prospects for the indirect use in practice of certain patterns" that exist between two languages [Fedorov 1983: 130]. In our case, it is assumed that students are already familiar with the theory of interlingual transformations. Therefore, the task of the exercises on translational transformations is to systematize the theoretical knowledge of students, to stimulate thought, to prompt possible options, to study the tactical methods of translation in order to form translational thinking. To develop the ability to identify correctly the translational task. 
7. Paraphrasing. Practice shows that students, when formulating phrases in the process of translation, make long pauses, get lost, do not know how to start, believing that the translation variant may be only one, etc. Paraphrasing exercises are very helpful for future translators. They contribute to the development of speech flexibility. We develop the ability to "vary the means of language expression" for an optimal translation solution by offering several variants of one sentence, [Latyshev, Semenov 2008: 178]. Right selection of different variants of sentence translation will help to come to the optimal translation solution and to minimize translation mistakes such as selfrepetition, omission, addition, lexical and grammatical mistakes.

8. Recording, video annotation. This type of task is done for visualauditory perception of information. The future specialist will have to face the translation of the video (for example, advertising), or interview. The advantage of working with video interviews is that students perceive the unprepared conversation of people whose history undoubtedly deserves attention. The perception of the sounding text is complicated by the accents of the speakers, in some cases by speech defects and, at the same time, they are full of facts, ideas and terminology. Background information, stable phrases, clichés are included in this material. After watching a video interview, students will orally present in Ukrainian the content they have seen. The main goal of the exercise is to develop the skills directed to correct and logical presentation of the material.

\section{References}

1. Bassanett S. Translation studies. 3rd edition. London and New York: Routledge, 2005. 176 p. 2. Bell R.T. Translation and translating: Theory and Practice (Applied Linguistics and Language Study) Text / R.T. Bell, Ch. Candin. London: Longman, 1991. 298 p. 3. Catford J.C. A linguistic theory of translation. London, Oxford University Press, 1965. 103 p. 4. Riccardi A. Translation studies. Perspectives and emerging discipline. Cambridge: Cambridge University Press, 2002. 215 p. 5. Retsker Y.I. (2010). Osnovnye etapy podgotovki perevodchika (Iz opyta prepodavaniya perevoda s angliyskogo yazyka) [The main stages of translator training (From the experience of teaching translation from English)], Mosty. №3(27). M.: Izdatel OOO "P. Vallent", 2010. C. 3-11. [in Russian]. 6. Alekseeva I.S. (2008). Prosessionalny trening perevodchika: uchebnoye posobite po ustnomu i pismennomu perevodu dlya perevodchikov i prepodavateley. [Translator's Professional Training: Interpretation and Translation Manual for Translators and Teachers]. «Soyuz» [in Russian]. 7. Chuzhakin A.P. (2009). Vvedeniye $\mathrm{v}$ ustnyy perevod. Introduction to consecutive interpreting. Tipy/vidy ustnogo perevoda, protokolpoisk raboty, korporativnaya kultura [Introduction to interpretation. Introduction to consecutive interpreting. Types/types of interpretation, protocol, job search, corporate culture.]. M.: INSA. [in Russian]. 8. Minyar-Beloruchev R.K. Obshchaya toriya perevoda i ustnyy perevod [General theory of translation and interpretation]. M.: Voenizdat. [in 
Russian]. 9. Komissarov V.N. Teoreticheskie osnovy metodiki obucheniya perevodu [The theoretical basis of teaching translation]. M.: Rema. [in Russian].

Демченко Н.О. Вибір і організація навчального матеріалу для навчання перекладачів послідовному перекладу

В умовах сучасності особливої актуальності набуває соціальне замовлення на підготовку усних перекладачів в рамках мовної освіти, яка забезпечувала б досягнення поставлених завдань в мінімальні терміни 3 найменшою витратою сил i засобів. Формування особистості перекладача та його професійної компетентності, а також оптимізація процесу викладання перекладу визначає зміст всього навчального процесу. Якість вищої освіти характеризується значною професійною орієнтацією навчального процесу, профільним вибором навчального матеріалу, який, у свою чергу, повинен бути зосереджений як на досягнутому, так і на перспективному рівні знань і вмінь. Питання підготовки студентів до перекладу в цілому та усному, зокрема, традиційно представляли значний інтерес. Основною метою статтї $\epsilon$ обговорення сучасних концепцій викладання усного послідовного перекладу та формування професійної компетентності перекладу у підготовці фахівців вищої освіти. У статті представлени обгрунтовані вимоги до вибору навчальних матеріалів, та блокі вправ для викладання усного послідовного перекладу студентів- лінгвістів.

Ключові слова: послідовний переклад, інтерпретація, спілкування, перекладач, навчальні вправи, навчальний матеріал

Демченко Н.А. Выбор и организация учебного материала для обучения переводчиков последовательному переводу

В условиях современности особую актуальность приобретает социальный заказ на подготовку устных переводчиков в рамках языкового образования. Подготовка переводчиков приобрела первостепенное значение. Формирование личности переводчика и его профессиональной компетентности наряду с оптимизацией процесса обучения переводчиков-лингвистов определяет содержание всего образовательного процесса. Качество высшего образования характеризуется значительной профессиональной направленностью образовательного процесса, профильно-ориентированным подбором учебного материала, который, в свою очередь, должен быть ориентирован как на достигнутый, так и на перспективный уровень знаний и навыков.

Основной целью данной статьи является обсуждение современной концепции обучения устному последовательному переводу и формированию профессиональной переводческой компетенции при подготовке специалистов в высшей школе. В статье представлены 
требования к отбору учебных материалов и блоки упражнений при обучении устному последовательному переводу студентов-лингвистов.

Ключевые слова: последовательный перевод, устный перевод, общение, переводчик, учебные упражнения, учебный материал.

\section{Demchenko N.O. Choice and organization of educational material for interpreters training consecutive translation}

Over the past decades new social and political conditions put forward the necessity to train specialists who are able to promote mutual understanding between nations and to provide access to the diversity of world politics and culture. A social order for interpreters training has become of primary importance. The formation of the interpreter personality and his professional competence determines the content of the entire educational process. Higher school learning process has its own specifics. The quality of higher education is characterized by a significant professional orientation of the educational process, a profile-oriented selection of educational material, which, in turn, should be focused on both the achieved and the promising level of knowledge and skills. The issue of training the students to translate in general and interpret in particular has traditionally been of considerable interest. The primary aim of this paper is to discuss modern concept of teaching oral consecutive translation and the formation of professional translation competence in the training of specialists in higher education The article present the requirements for the selection of educational materials and blocks of exercises in teaching students oral consecutive translation. This information can be helpful for organization of work with the students whose specialty is translation. The materials must be original. The selection of the original material corresponds to the linguistic purpose of learning and is also able to increase the motivation of students. Textual material should be supplied with explanations, comments and commentaries. The teaching material should take into consideration the specific features of oral speech; thereby make the training translation closer to the real conditions of a professional translator work. Great attention should be paid to the selection of audio and video materials.

Key words: sequential translation, interpretation, communication, interpreter, training exercises, educational material.

Стаття надійшла до редакції - 05.04.2019 р.

Стаття прийнята до друку - 08.04.2019 р.

Рецензент - д.філ.н, проф. ЛНУ імені Тараса

Шевченка Моісеєнко О.Ю. 